\title{
Rubenstein's Analysis of the Humanitarian INGOs: The Political Ethics of Decision Making Processes
}

\author{
Jennifer C. Rubenstein, Between Samaritans and States - The Political \\ Ethics of Humanitarian INGOs (Oxford University Press, 2015)
}

Jennifer C. Rubenstein, in her new book Between Samaritans and States The Political Ethics of Humanitarian INGOs, constructs a theory of INGO political ethics which can be applied to find solutions for challenging ethical predicaments which INGOs often face. She asserts that in donor countries, the humanitarian INGOs are often regarded as angelic good Samaritans, or naive miscreants wandering down the primrose path, as opposed to narrowly selfinterested, profit driven corporations. To differentiate the naïve miscreants or coldly self-interested corporations, INGOs wish to address humanity's concerns in an ethically sensitive way. The actions of INGOs can sometimes lead to negative unintended results regardless of the original set of good intentions. At this point, Rubenstein emphasizes the need for an INGO political ethics which would sustain a map of different features of INGOs with a cartographic approach to analyze the ethical problems in a detailed manner.

Rubenstein analyzes the six INGOs which are headquartered in wealthy Western countries. These include CARE, Catholic Relief Services, MSF, Save the Children, World Vision and Oxfam. She excludes the INGOs that do exclusively development work such as the International Development Exchange (IDEX), since they do not deal with challenges associated with working on the ground in conflict zones or allocating resources for emergencies or non-emergencies. She also excludes the NGOs in aid-recipient countries from her analysis since they are less likely to be the second-best actors and less likely to deal with the quandary of second-best. She excludes the foundations such as Gates Foundation since they do not rely on ongoing contributions from the general public, and so do not face the ethical challenges associated with the need to raise funds from the general public. She focuses on actors rather than specific cases because doing so allows her to consider how INGOs allocate resources among different situations.

Her book draws on semi-structured interviews, participant observation, and archival research that she conducted over the course of nine months with the International Committee of the Red Cross [ICRC], MSF-France, MSF-Belgium, MSF-Amsterdam, Oxfam-UK and the International Rescue Committee (IRC) in 2001-2. She also shadowed an IRC aid worker for two weeks in northern 
Uganda. The goal of this research was to better understand the political and ethical predicaments that aid workers face, the considerations that inform their decisions about how to respond to those predicaments and the constraints under which they operate.

Humanitarian INGOs have three main features that make them a distinctive type of actor. First, humanitarian INGOs engage in governance. Humanitarian INGOs serve governance functions analogous to those served by conventional domestic governments as sole providers of basic goods and service. In some places they replace key state functions providing for the health, welfare and safety of citizens. They also engage in global governance by causally influencing other international and supranational institutions such as the World Bank and by helping to constitute the international humanitarian order. Second, even they are not engaged in conventional or global governance, humanitarian INGOs are highly political. Despite of the fact that the INGOs claim that they stay out of politics even when they are not engaged in governance they are political in the sense that they have effects that are themselves political or that happen as a result of political dynamics from which humanitarian INGOs cannot extricate themselves. They also help to shape widely shared understandings that themselves have political effects.

Despite their significant diversity humanitarian INGOs are a distinctive type of political actor. They occupy a space between Samaritans and states because, a) they engage in governance for more than the prototypical individual good Samaritan, b) they differ from full-fledged governments in important ways. Rubenstein analyzes what types of ethical predicaments humanitarian INGOs regularly face. She classifies them as four important types of predicaments: 1the problem of spattered hands 2- the quandary of the second-best 3) the costeffectiveness conundrum 4) the moral motivation trade-off. The book offers a map of these predicaments. In each part, she describes the structure in detail with giving specific examples of the conflict situations. A utilitarian approach can lead to a morally wrong action, and results in the problem of 'dirty hands.' The problem of 'spattered hands' arises in the context of basic service provision by INGOs in conflict settings. Adopting the spattered hands framework helps in dealing with decisions on whether stay or go from conflict areas. The quandary of the second-best arises in the context of political advocacy by INGOs. The cost-effectiveness conundrum arises in context of large-scale decisions about resource use and the moral motivation trade-off as it arises in the context of INGOs portrayal-related practices (creating, publishing, and facilitating the creation and publication of images of famine and severe poverty). Rubenstein later discusses how these four ethical predicaments intersect. She argues that just as a topographic map of a terrain shows the mountains, deserts and rivers that 
travelers crossing that terrain must navigate a map of the ethical predicaments that humanitarian INGOs face highlights the various ethical responsibilities and practical constraints that these organizations must navigate. Her political ethics theory offers conceptual descriptions with normative implications but it is not narrowly prescriptive.

While responding to ethical predicaments, she argues that the question is not how they can avoid all moral compromise but to define which moral compromises should be respected, and which should we grudgingly accept. The normative standards that she brings to bear in answering these questions are democratic egalitarian, humanitarian and justice-based norms. One of the main questions in this book is how does a close study of humanitarian INGO political ethics broaden our understanding of democratic, humanitarian, egalitarian and justice based norms. In the analysis, she asks three specific questions about the norms. Namely, which norms are relevant to a given INGO activity? How should these norms be interpreted and specified for the context of that activity and how do relevant specifications of relevant norms support or conflict with each other?

She lists the eight extant alternatives as the roles of INGOs: INGOs social role is described as that they are rescuers of the poor and disaster-affected people they seek to assist. They are equal partners with domestic NGOs based in the countries where they work and agents for their donors. INGOs are or should be agents for their intended beneficiaries and accountable to their intended beneficiaries. The sixth conception is the idea that traditional principles of traditional humanitarianism such as humanity and impartiality offer a sufficient basis for an account of humanitarian INGO political ethics. Some critics of the INGOs suggests that developing an account of humanitarian INGO political ethics is beside the point because INGOs are no better that multi-national corporations and/or are neo-colonial. All of these alternatives cannot offer an adequate account of INGO political ethics or make a persuasive case that such an account is beside the point. Although there is much repetition in the book, Rubenstein makes her points clearly in an incremental manner by offering some solid examples of conflict situations which INGOs face. Overall, she brings a practical and solid approach by providing an ethical method with which to deal with humanity's many challenges.

EdaKeskin

Philosophy

Martin-Luther-Universität Halle-Wittenberg, Germany

Email:edakeskin83@gmail.com

\section{the global justicenetwork}

